\title{
UJI KOMPETENSI PADA BUKU SEKOLAH ELEKTRONIK (BSE)
}

\author{
Oleh: \\ Nur Holifatuz Zahro \\ Program Studi Pendidikan Guru Sekolah Dasar Fakultas Keguruan dan Ilmu Pendidikan, \\ Universitas Abdurachman Saleh Situbondo \\ J1. PB Sudirman No. 7 Situbondo \\ Email: holifatuzzahro@gmail.com
}

\begin{abstract}
Abstrak: Evaluasi merupakan bagian dari proses belajar mengajar yang secara keseluruhan tidak dapat dipisahkan dari kegiatan mengajar. Dalam hubungannya dengan evaluasi dan proses belajar mengajar, diperlukan suatu buku penunjang pembelajaran Bahasa Indonesia yang didalamnya terdapat evaluasi yang tepat. Buku Aktif dan Kreatif Berbahasa Indonesia untuk Kelas XI SMA/MA Program IPA dan IPS merupakan buku pegangan siswa dan guru yang diterbitkan oleh pemerintah melalui media internet yang disebut dengan Buku Sekolah Elektronik (BSE). Buku tersebut bisa diakses oleh pendidik dan pelajar di seluruh Indonesia karena dapat diperoleh secara mudah melalui internet. Berdasarkan hasil penelitian Bentuk tes soal uji kompetensi pada Buku Sekolah Elektronik (BSE) ditemukan semua soal berbentuk tes objektif berjenis pilihan ganda. Berdasarkan struktur soalnya, soal uji kompetensi tersebut digolongkan menjadi 4, yaitu (1) pertanyaan langsung-daftar pilihan terdapat 25 soal, (2) pernyataan tidak lengkap-daftar pilihan terdapat 19 soal, (3) tekspenyataan tidak lengkap-daftar pilihan terdapat 6 soal, dan (4) perintah-tekspernyataan tidak lengkap-daftar pilihan terdapat 30 soal. Tingkat kognitif soal uji kompetensi pada Buku Sekolah Elektronik (BSE) dilihat berdasarkan teori Bloom ditemukan tingkat pengetahuan (C1) terdapat 8 butir soal dengan persentase $14 \%$, tingkat pemahaman (C2) terdapat 22 bitir soal dengan persentase $38 \%$, tingkat penerapan (C3) terdapat 10 butir soal dengan persentase $18 \%$, tingkat analisis (C4) terdapat 16 butir soal dengan persentase $27 \%$, tingkat sintesis (C5) terdapat 2 butir soal dengan persentase 3\% dan tidak ditemukan soal dengan tingkat evaluasi(C6) dengan persentase $0 \%$ dengan sajian soal berbentuk kalimat deklaratif dan interogatif
\end{abstract}

Kata Kunci: Uji Komptensi, Tes Kognitif, Evaluasi 


\section{PENDAHULUAN}

Keberhasilan dalam pembelajaran bahasa dan sastra Indonesia merupakan harapan dari semua pihak. Keberhasilan tersebut dapat dilihat dari ketercapaian tujuan pembelajaran yang telah dirumuskan. Menurut Purwanto (1992:5) untuk mengetahui tingkat keberhasilan program pembelajaran perlu dilakukan evaluasi. Evaluasi yang dilakukan dalam pembelajaran mempuyai posisi yang sangat penting. Keberadaannya tidak dapat dihapus atau digantikan dengan kegiatan lain. Menurut Sukardi (2009:12) evaluasi merupakan bagian dari proses belajar mengajar yang secara keseluruhan tidak dapat dipisahkan dari kegiatan mengajar.

Evaluasi merupakan tahapan terakhir dalam sebuah pembelajaran yang memiliki beberapa fungsi. Secara rinci Purwanto (1992:5-7) mengelompokkan fungsi evaluasi menjadi empat, yaitu:(a) untuk mengetahui kemajuan dan perkembangan serta keberhasilan siswa setelah mengalami atau melakukan kegiatan belajar selama jangka waktu tertentu, (b) untuk mengetahui tingkat keberhasilan program pengajaran, (c) untuk keperluan Bimbingan dan Konseling, dan (d) untuk keperluan pengembangan dan perbaikan kurikulum sekolah yang bersangkutan.

\section{Dalam hubungannya}

dengan evaluasi dan proses

belajar mengajar, diperlukan suatu buku penunjang pembelajaran Bahasa Indonesia yang didalamnya terdapat evaluasi yang tepat.
Pemerintah bertekad menyediakan buku paket untuk sekolah, mulai dari SD hinggga SLTA (Suladi, 2000: 7). Salah satu buku penunjang Bahasa Indonesia yang berjenjang SMA/MA adalah buku Aktif dan Kreatif Berbahasa Indonesia untuk Kelas XI SMA/MA Program IPA dan IPS yang disusun oleh Abdul Adi Somad,dkk. Buku Aktif dan Kreatif Berbahasa Indonesia untuk Kelas XI SMA/MA Program IPA dan IPS merupakan buku pegangan siswa dan guru yang diterbitkan oleh pemerintah melalui media internet yang disebut dengan Buku Sekolah Elektronik (BSE). Buku tersebut bisa diakses oleh pendidik dan pelajar di seluruh Indonesia karena dapat diperoleh secara mudah melalui internet.

Meskipun Buku Sekolah Elektronik (BSE) karangan Adi Abdul Somad,dkk tersebut telah lulus seleksi namun soal uji kompetensi yang ada di dalamnya perlu dikaji. Hal ini disebabkan oleh keberadaan soal uji kompetensi tersebut sangat penting untuk mengukur ketercapaian kompetensi yang diharapkan dalam proses pembelajaran. Berdasarkan permasalahan yang telah diuraikan diatas maka dalam kajian ini akan dibahas tentang $U j i$ Kompetensi pada Buku Sekolah Elektronik (BSE) Karangan Adi Abdul Somad,dkk.

\subsection{Rumusan Masalah}

Masalah yang diteliti dalam kajian ini adalah sebagai berikut.

1) Bagaimanakah bentuk tes uji kompetensi pada Buku Sekolah Elektronik(BSE) karangan Adi Abdul Somad,dkk? 
2) Bagaimanakah tingkat kognitif uji kompetensi pada Buku Sekolah Elektronik(BSE) karangan Adi Abdul Somad,dkk menurut teori Bloom?

3) Bagaimanakah bentuk kalimat uji kompetensi pada Buku Sekolah Elektronik(BSE) karangan Adi Abdul Somad,dkk dilihat dari segi sintaksis kebahasaannya?

\subsection{Tujuan penelitian}

Penelitian ini bertujuan untuk mendeskripsikan:

1) bentuk tes uji kompetensi pada Buku Sekolah Elektronik(BSE) karangan Adi Abdul Somad,dkk

2) tingkat kognitif 1 uji kompetensi pada Buku Sekolah Elektronik(BSE) karangan Adi Abdul Somad,dkk menurut teori Bloom; dan

3) bentuk kalimat uji kompetensi pada Buku Sekolah Elektronik(BSE) karangan Adi Abdul Somad,dkk menurut teori Bloom.

\subsection{Manfaat penelitian}

Manfaat yang diharapkan dari penelitian ini adalah sebagai berikut. 1) Bagi pemerintah, khususnya Departemen Pendidikan Nasional, hasil peneitian ini dapat dijadikan bahan koreksi untuk penerbitan buku pegangan berikutnya.

2) Bagi guru, hasil penelitian ini dijadikan masukan dalam menyusun alat evaluasi yang tepat bagi pesarta didik.
3) Bagi mahasiswa FKIP, hasil penelitian ini dapat dijadikan rujukan pada mata kuliah Evaluasi Pembelajaran.

4) Bagi peneliti lain, hasil penelitian dapat dijadikan bahan kajian lebih lanjut dengan ruang lingkup yang lebih luas.

Dalam dunia pendidikan, kegiatan evaluasi merupakan hal yang penting dalam proses pembelajaran. Evaluasi merupakan alat untuk mengetahui kemajuan dan perkembangan peserta didik setelah proses pembelajaran. Selain itu, evaluasi juga sebagai alat untuk mengetahui kompetensi yang telah tercapai sesuai dengan tujuan pembelajaran.

Secara garis besar, alat evaluasi dalam dunia pendidikan dapat dibedakan menjadi dua macam bentuk, yaitu nontes dan tes (Sukardi, 2009:11). Bentuk nontes, dipergunakan untuk mendapatkan informasi tentang keadaan testi (siswa) tanpa dengan alat tes (Nurgiyantoro, 2001:54). Evaluasi yang menggunakan bentuk nontes dilakukan jika informasi yang diharapkan berupa tingkah laku afektif dan psikomotor.

Tes merupakan pemberian tugas atau pertanyaan yang harus dikerjakan oleh siswa (testi,tercoba) yang sedang dites (Nurgiyantoro, 2009:59). Selanjutnya berdasarkan jawaban yang dikehendaki yang diberikan siswa, Nurgiyantoro(2009:59) membagi tes ke dalam tes perbuatan dan tes verbal. Tes perbuatan adalah tes yang menuntut respon para siswa berupa tingkah laku yang melibatkan gerakan otot. Tes perbuatan 
dimaksudkan untuk penilaian aspek

psikomotor.

Alat evaluasi yang digunakan dalan buku pegangan adalah tes tertulis. Tes tertulis dibedakan menjadi dua bentuk, yaitu tes objektif dan tes esai (Sukardi,2009:11).

\section{Tes Objektif}

Tes objektif menurut Arifin (1988:32) adalah tes yang menuntun siswa untuk memilih jawaban yang benar diantara kemungkinan jawaban yang telah disediakan, memberikan jawaban singkat, dan melengkapi pertanyaan-pertanyaan yang belum sempurna. Tes ini dikatakan objektif karena siswa tidak dituntut merangkai jawaban atas dasar informasi yang dimilikinya, namun berdasarkan pilihan jawaban yang ada.

\section{Selanjutnya, Sukardi}

(2009:117) mengungkapkan bahwa tes objektif jenis pilihan banyak digunakan para guru (evaluator). Pada tes objektif jenis pilihan siswa diharuskan memilih satu jawaban benar dari sejumlah jawaban yang telah disediakan oleh evaluator. Tes objektif jenis pilihan yang banyak digunakan adalah tes jawaban benar-salah, pilihan ganda, isian, dan penjodohan

(Nurgiyantoro,2009:79)

a. Tes Benar-salah

Tes benar-salah adalah bentuk tes yang terdiri dari sebuah pernyataan yang mempunyai dua kemingkinan, yaitu benar atau salah.berikut dikemukakan beberapa contoh.
Bahasa Indonesia termasuk rumpun Austronesia.(ingatan)

B-S Kalimat minor

adalah kalimat yang hanya mengandung unsure subjek dan predikat saja, jika ada unsur objek dan keterangan namanya kalimat mayor. (pemahaman)

\section{b. Tes Pilihan Ganda}

Tes pilihan ganda merupakan suatu bentuk tes yang paling banyak digunkan dalam dunia pendidikan. Pada hakikatnya, tes pilihan ganda tak berbeda dengan tes benarsalah. Tes pilihan ganda juga memberikan pernyataan benar dan salah pada setiap alternatif jawaban.

Sukardi (2009:117) menambahkan, bahwa tes objektif jenis pilihan ganda pada prinsipnya terdiri atas sebuah pokok persoalan dan daftar pilihan yang dianjurkan untuk diisi oleh siswa yang hendak dievaluasi.

Pokok persoalan adalah bagian inti yang berisi hasil pembelajaran yang hendak ditanyakan kepada siswa. Selanjutnya Sukardi (2009:117) membedakan pokok persoalan pada tes objektif jenis pilihan menjadi dua, yaitu pertanyaan langsung dan pernyataan tidak lengkap. Pokok persoalan dikatakan menggunakan pertanyaan langsung, apabila bentuk kalimat yang digunakan adalah bentuk kalimat tanya. Pokok persoalan dikatakan tidak lengkap 
apabila evaluator mengonstruksi kalimat dalam bentuk pernyataan dengan masih diperlukan siswa untuk mengisi dengan jawaban yang paling benar.

Contoh butir soal objektif dengan pertanyaan langsung.

Kota manakah yang merupakan ibu kota Jawa Tengah?
a. Semarang
b. Bandung
c. Surabaya
d. Ambarawa

\section{c. Tes Isian}

Tes isian, melengkapi, atau menyempurnakan merupakan suatu bentuk tes objektif yang terdiri dari pernyataanpernyataan yang disengaja dihilangkan sebagian unsurnya, atau yang sengaja dibuat secara tidak lengkap. Unsur yang dihilangkan atau belum ada merupakan hal yang ditanyakan kepada siswa. Berikut dikemukakan beberapa contoh tes melengkapi.

- Kalimat yang paling tidak memiliki unsur subjek dan predikat disebut kalimat.....

- Unsur kebahasaan terkecil yang membedakan makna disebut....

- Kalimat....adalah kalimat yang predikatnya sebuah kata kerja.

d. Tes Penjodohan

Dalam bentuk tes penjodohan, siswa dituntut untuk menjodohkan, mencocokkan, menyesuaikan, atau menghubungkan antara dua pernyataan yang disediakan.

Pernyataan biasanya diletakkan pada dua lajur, lajur kiri dan kanan, lajur kiri berupa pernyataan pokok atau pertanyaan dan lajur kiri merupakan jawabannya. Di bawah ini contoh tes penjodohan.

1) Kata sayur-sayur berubah menjadi sayurmayur karena mengalami proses... a.nominal

2) Kalimat yang berpredikat selain kata kerja disebut... b.asimilasi

\section{Tes Esai}

Tes Esai adalah salah satu bentuk tes tertulis yang tersusun atas butir-butir soal yang menuntut uraian kata. Menurut Grounlund(dalam Sukardi,2009:94) tes esai dibedakan menjadi dua, yaitu tes esai dengan jawaban panjang dan tes esai dengan jawaban pendek.

Tes esai dengan jawaban panjang adalah tes yang memerlukan jawaban secara luas. Jenis tes tersebut memberi kesempatan pada siswa untuk memberikan jawaban secara tuntas dan jelas. Selain itu siswa juga diberi kesempatan untuk mengorganisasi penuangan ide tersebut menjadi satu kesatuan sehingga mudah dipahami oleh siswa.

Tes esai dengan jawaban pendek bertujuan untuk meminta jawaban secara singkat dan tepat. Jawaban pada soal tes esai ini lebih mengarah pada jawaban yang 
lebih spesifik dan lebih pasti seperti kunci jawaban yang telah dibuat evaluator.

Contoh tes yang berbentuk esai adalah sebagai berikut.

Reso : Duh Gusti! Bahwa kamu bisa lebih mampu mengatur negara itu aku tidak ragu. Tetapi, jangan kamu bertindak kejam kepada putra kita.

Dara : la bukan putra Anda. Dan, bukan lagi putra saya.

Reso : Jadi, kamu benar-benar bertekad untuk menobatkan diri menjadi Raja?

Dara : Kenapa tidak, bila saya merasa kuat dan bisa membuktikan bahwa kuat? Bukankah Anda bisa menjadi andalan saya yang utama? Bila Anda ragu-ragu untuk memanggil pembunuh itu, saya bisa bertindak sendiri dengan cara saya! (pergi)

Reso : Aryo Sekti, Anda saksikan sendiri sekarang bagaimana unsur yang tidak terduga telah membantu usaha ke arah citacita kita!

Sekti : Ya. Memang! Dan saya juga menyaksikan bagaimana mengerikannya sihir gaib dari tahta. Sebenarnya sekarang ini hati saya menjadi kecut. Akan tetapi, demi keutuhan dan kejayaan kerajaan, saya tidak akan mundur dalam membantu usaha Anda.

Sumber: Drama Panembahan Reso, 1998
Sebutkan unsur intrinsik apa saja yang ada pada penggalan dialog drama di atas?

\section{Tingkat Kognitif}

Evaluasi merupakan kegiatan penting dalam pembelajaran. Evaluasi berfungsi sebagai alat untuk mengetahui sejauh mana siswa memahami pelajaran yang telah diberikan yang bersifat kognitif. Menurut Bloom (dalam Sukardi,2009:75) tingkat kognitif dibedakan menjadi enam tingkatan, yaitu knowledge / pengetahuan (C1), comprehension / pemahaman (C2), application / penerapan (C3), analysis / analisis (C4), synthesis/sintesis (C5), dan evaluatio /evaluasi (C6).

Dalam penyusunan tujuan instruksional, keenam tingkatan ini pada umumnya ditunjukkan dengan beberapa kata-kata kerja. Selanjutnya Bloom (dalam Parera, 1983:5) mendaftar kata kerja operasional untuk setiap jenjang kognitif sebagai berikut:

a. pengetahauan $(\mathrm{Cl})$, kata kerja yang digunakan adalah mendefinisikan, mendeskripsikan, menanamkan, mendaftar, menjodohkan, mempertahankan, membedakan;

b. pemahaman $(C 2)$, kata kerja yang digunakan adalah mengubah, mempertahankan, membedakan, menafsirkan, menjelaskan, menerangkan, memperluas, mengeneralisasikan, memberi contoh, menyimpulkan, membuat para frase, meramalkan, menulis kembali, meringkas; 
c. aplikasi/penerapan $(C 3)$, kata kerja yang digunakan adalah mengubah, menghitung, mendemonstrasikan, menemukan, memanipulasi, memodifikasi, mengoperasikan, meramalkan, menghasilkan, menghubungkan, memecahkan, mempergunakan;

d. analisis $(C 4)$, kata kerja yang digunakan adalah merinci, mendiagramkan, membedakan, mengidentifikasi, mengilustrasikan, menyimpulkan, menunjukkan, memilih, memisahkan, membagi;

e. sintesis(C5), kata kerja yang digunakan adalah mengkatagorikan, mengkombinasikan, menyusun, mengarang, menciptakan, mendesain, merencanakan, menulis kembali, meringkas, menceritakan;

f. evaluasi(C6), kata kerja yang digunakan adalah menilai, memandingkan, menyimpulkan, mempertentangkan, mengkritik, mendeskripsikan, membedakan, menjelaskan, membenarkan, memutuskan, menafsirkan, menghubungkan, meringkas, menyokong.

Seperti yang telah disebutkan, jenis evaluasi/uji kompetensi dalam tingkat kognitif teori Bloom ada enam, yaitu sebagai berikut.

$$
\begin{gathered}
\text { a. Tingkat Pengetahuan }(C 1) \\
\text { Soal pada tingkat }
\end{gathered}
$$

pengetahuan bertujuan agar siswa

menyebutkan kembali fakta, definisi, atau konsep. Contoh:
1) Penulis novel Laskar Pelangi adalah...

2) Bahasa Indonesia termasuk rumpun... .
a. Polinesia
b. Austronesia*
c. Melanesia
d. Indojerman

b. Tingkat Pemahaman $(C 2)$

Soal pada tingkat pemahaman dimaksudkan untuk mengukur pemahaman siswa tentang adanya hubungan antara hal, sebab akibat, perbedaan dan persamaan antarhal, dan sebagainya. Contoh:

1) Mengapa Lintang harus memutuskan untuk tidak bersekolah?

2) Di antara kalimat-kalimat berikut yang merupakan kalimat nominal adalah...

a. Anak itu pemalu sekali*

b. Pekerjaan ayahnya bercocok tanam

c. Setiap hari pasti ia membaca surat kabar

d. Novel itu telah selesai dibacanya

c. Tingkat Penerapan (C3)

Soal pada tingkat penerapan menghendaki siswa mampu menerapkan atau memberikan contoh baru. Misalnya suatu konsep, pengertian, atau pandangan yang ditunjukkan dalam bacaan. Contoh: 
1) Berdasarkan bacaan di atas, buatlah sebuah paragraf dengan kalimatmu sendiri!

2) Kata-kata yang dikutip dari wacana di atas berikut mengalami proses nominalisasi, kecuali... . a. Mahalnya
b. Keluhan
c. Umumnya*
d. Kebutuhan

\section{d. Tingkat Analisis (C4)}

Soal tingkat analisis menuntut siswa mampu menganalisis informasi tertentu pada sesuatu, mengenali, mengidentifikasi, membedakan pesan atau informasi, dan sebagainya. Contoh:

1) Unsur intrinsik apa saja yang terdapat dalam penggalan novel di atas?

2) Kalimat "Walaupun hari akan hujan, tetapi ia tetap pergi juga" salah, sebab... .

a. Kalimat mengalami kerancuan, kata sambung "walaupun" dipakai dalam kalimat majemuk bertingkat, sedang kata "tetapi" untuk kalimat majemuk setara.*

b. Kalimat mengalami kerancuan, kata sambung "tetapi" seharusnya diganti dengan kata sambung yang lain.

c. Kalimat terdiri dari dua klausa, tetapi yang pertama tidak jelas subjeknya.

d. Kata sambung "walaupun" dan "tetapi" mestinya dipakai salah satu saja atau diganti dengan kata "meskipun" dan "namun".

e. Tingkat Sintesis (C5)

Soal pada tingkat sintesis menuntut siswa untuk mampu menghubungkan antara beberapa hal, menyusun hal-hal tertentu menjadi struktur baru, atau melakukan generalisasi. Hasil kerja kognitif sintesis menunjukkan cara berpikir siswa. Oleh karena itu, bentuk soal yang dipergunakan biasanya adalah bentuk subjektif, namun tidak menutup kemungkinan menggunakan bentuk objektif. Contoh:

1)

$$
\begin{array}{ll}
\text { Apa pengaruh kebijakan } \\
\text { perdagangan } & \text { terhadap } \\
\text { perekonomian rakyat? } &
\end{array}
$$

2) Bahasa Indonesia dipergunakan oleh berbagai lapisan masyarakat, lembaga, media massa, dan sebagainya, dan tidak semata-mata oleh guru bahasa

Indonesia saja.

Jelaskan mengapa usaha pengembangan dan pembinaan bahasa Indonesia secara baik dan benar tidak mungkin berhasil jika hanya ditangani oleh para guru bahasa Indonesia dan pusat bahasa!

\section{f. Tingkat Evaluasi (C6)}

Soal pada tingkat evaluasi bertujuan agar siswa mampu memberikan penilaian 
terhadap suatu hal, kasus atau situasi yang dihadapi dengan berdasar pada acuan tertentu. Misalnya penilaian terhadap isi wacana dapat berupa konsep, gagasan, cara pemecahan masalah dan sebagainya. Sedangkan penilaian terhadap cara penuturan dalam wacana dapat berupa efektivitas cara penyajian masalah, hahal yang berkaitan dengan bahasa misalnya gaya penuturan, kejelasan, ketepatan, dan sebagainya. Contoh:

1) Manakah yang terbaik di antara hasil-

hasil karya Chairil Anwar?

Penyakit muntaber sedang landa daerah itu sejak beberapa waktu lalu. Oleh karena itu, walaupun sekolah mestinya sudah jalan seminggu, namun masih kelihatan sepi-sepi saja. Guru-gurunya juga baru beberapa saja yang sudah nampak hadir. Untuk segera menanggulangi daripada musibah itu, maka pemerintah sudah mengarahkan para tenaga-tenaga medis daripada daerah-daerah lain.

Mengapa wacana yang dikutip diatas tidak memenuhi syarat penuturan dalam bahasa Indonesia yang benar?

Dalam penilaian/evaluasi, haruslah meliputi semua tingkat kognitif yang ada, mulai dari tingkat pengetahuan hingga tingkat evaluasi. Hanya, yang perlu diperhatikan adalah proporsi atau perbandingan dari keenam tingkat kognitif itu tentunya tidak sama besar (Nurgiyantoro,2001:39). Proporsi atau perbandingan tersebut didasarkan pada perkembangan kognitif siswa. Perkembangan kognitif siswa SD tentu berbeda dengan siswa SMP atau SMA. Kemudian Nurgiyantoro (2010: 40) membuat suatu tabel yang menggambarkan perimbangan proporsi penilaian untuk keenam tingkat kognitif bagi siswa SD,SMP dan SMA.

Tabel 1.Perimbangan Proporsi Penilaian

Keenam Tingkat Kognitif untuk Siswa SD,SMP, dan SMA

\begin{tabular}{|c|c|c|c|c|c|c|c|}
\hline \multicolumn{8}{|c|}{$\begin{array}{l}\text { Ti ng kat Ko } \\
\text { Persentase } \\
\text { gni tif }\end{array}$} \\
\hline $\begin{array}{l}\text { Ti } \\
\text { ng } \\
\text { kat } \\
\text { Se } \\
\text { kol } \\
\text { ah }\end{array}$ & $\begin{array}{l}\text { In } \\
\text { gat } \\
\text { an } \\
\text { (C } \\
1)\end{array}$ & $\begin{array}{l}\text { Pem } \\
\text { aha } \\
\text { man } \\
(\mathrm{C} 2)\end{array}$ & $\begin{array}{c}\text { Pen } \\
\text { erap } \\
\text { an } \\
(\mathrm{C} 3 \\
)\end{array}$ & $\begin{array}{l}\text { An } \\
\text { ali } \\
\text { sis } \\
(C \\
4)\end{array}$ & $\begin{array}{l}\mathrm{Si} \\
\text { nte } \\
\text { sis } \\
(\mathrm{C} \\
5)\end{array}$ & $\begin{array}{l}\text { Ev } \\
\text { alu } \\
\text { asi } \\
\text { (C } \\
6)\end{array}$ & $\begin{array}{l}\mathbf{J u} \\
\mathbf{m l} \\
\mathbf{a h}\end{array}$ \\
\hline SD & 40 & 45 & 15 & - & - & - & $\begin{array}{c}10 \\
0\end{array}$ \\
\hline $\begin{array}{l}\mathbf{S} \\
\mathbf{M} \\
\mathbf{P}\end{array}$ & 35 & 40 & 20 & 5 & - & - & $\begin{array}{c}10 \\
0\end{array}$ \\
\hline $\begin{array}{l}\mathbf{S} \\
\mathbf{M} \\
\mathbf{A}\end{array}$ & 20 & 30 & 25 & 15 & 5 & 5 & $\begin{array}{c}10 \\
0\end{array}$ \\
\hline
\end{tabular}

\section{Kalimat}

Kalimat adalah bagian terkecil dari ujaran atau tulisan yang mengungkapkan pikiran yang utuh secara ketatabahasaan (Muslich, 1990:19). Menurut Alwi, dkk (2000:311) kalimat adalah satuan bahasa terkecil, dalam wujud lisan atau tulisan, yang mengungkapkan pikiran yang 
utuh. Dalam wujud lisan, ditandai dengan intonasi dan dalam bahasa tulis ditandai dengan tanda baca.

Kalimat memiliki berbagai macam jenis. Bila dilihat dari bentuk sintaksisnya dapat dibagi atas kalimat deklaratif, kalimat interogatif, kalimat imperatif dan kalimat eksklamatif (Alwi,dkk, 2000:352). Chaer (2009:187) membagi kalimat deklaratif, kalimat interogatif, kalimat imperatif dan kalimat interjektif berdasarkan modusnya, yaitu isi atau amanat yang ingin disampaikan oleh kalimatkalimat itu kepada pendengar atau pembacanya.

Kalimat eksklamatif atau kalimat interjektif adalah kalimat yang biasa digunakan untuk menyatakan perasaan kagum atau heran yang biasa ditandai dengan kata alangkah, betapa, atau bukan main (Alwi,dkk, 2000:362). Oleh karena itu, kalimat tersebut tidak dapat digunakan untuk evaluasi.

\section{Kalimat Interogatif (Kalimat Tanya)}

Kalimat interogatif adalah kalimat yang mengharapkan adanya jawaban secara verbal (Chaer, 2009:189). Cook (dalam Tarigan, 1984:22) berpendapat senada bahwa kalimat pertanyaan (kalimat interogatif) adalah kalimat yang dibentuk untuk memancing respon yang berupa jawaban. Kalimat interogatif diakhiri dengan tanda tanya (?). Jawaban yang diharapkan dapat berupa pengakuan, keterangan, alasan, atau pendapat dari pihak pendengar atau pembaca.
Ada tiga ciri formal yang menandai kalimat tanya, yaitu penggunaan intonasi tanya, kata tanya, dan partikel tanya.

a. Intonasi Tanya atau Tanda Tanya

Intonasi tanya menjadi ciri utama dalam kalimat tanya lisan. Dalam bahasa tulis, kalimat tanya diakhiri dengan tanda tanya (?) sebagai penanda intonasi tanya.

\section{b. Kata Tanya}

Penggunaan kata tanya sangat bergantung pada ha yang ditanyakan. Kata tanya yang biasa digunakan dalam kalimat tanya, antara lain apa, siapa, mengapa, kenapa, mana, bagaimana, bilamana, kapan dan berapa.

1) Kata tanya apa digunakan untuk menanyakan benda, identitas, kebenaran atau kepastian. Contoh: "Apa profesi sang narasumber?"

2) Kata tanya siapa biasa digunakan untuk menanyakan Tuhan, orang, malaikat, dan yang dianggap manusia, misalanya $\mathrm{Si}$ Manis atau Helly. Contoh kalimat tanya yang manggunkan kata tanya siapa adalah "Siapa yang menjadi tokoh utama dalam drama tersebut?"

3) Kata tanya mengapa biasanya digunakan untuk menanyakan sebab. Contohnya adalah "Mengapa Karim sangat membenci Mimi ?"

4) Kata tanya kenapa biasanya digunakan untuk menanyakan sebab seperti halnya kata tanya mengapa. Kata kenapa sering digunakan untuk bahasa lisan yang bersifat nonformal. Contoh kalimat tanya yang menggunakan kata tanya kenapa adalah 
"Kenapa kamu kemarin tidak masuk?"

5) Kata tanya mana sering digunakan untuk menanyakan pilihan dari suatu kelompok, contohnya "Kalimat mana yang menandakan ide pokok dalam paragraf diatas?"

6) Kata tanya mana juga digunakan untuk menanyakan keberadaan benda. Dalam hal ini, kata mana diawali dengan kata depan $d i, k e$ dan dari sehingga menjadi di mana, ke mana, dan dari mana. Contohnya, "Dari mana Bawang Putih menemukan labu emas itu?"

7) Kata tanya bagaimana biasanya digunakan untuk menanyakan keadaan atau cara untuk melakukan suatu perbuatan. Contohnya, "Bagaimana watak Karim dalam cerpen tersebut?"

8) Kata tanya bilamana dan kapan biasa digunakan untuk menanyakan waktu. Contoh kalimat yang menggunakan kata bilamana dan kapan adalah "Bilamana kamu mengantar pekerjaan itu?" dan

“Kapan bukuku akan kau kembalikan?”

9) Kata tanya berapa dipakai untuk menanyakan jumlah dan bilangan. Contohnya adalah "Berapa harga buku itu?"

\section{c. Partikel Tanya}

Dalam kalimat tanya, sering digunakan partikel tanya $-k a h$. Partikel $-k a h$ memiliki dua fungsi, yaitu untuk memperhalus pertanyaan dan untuk memberi tanda pada bagian yang dipentingkan atau penegasan.
1) Partikel -kah berfungsi untuk memperhalus pertanyaan dapat dilihat dari kalimatkalimat berikut.

1) Apa yang Anda inginkan?

2) Apakah yang Anda inginkan?

2) Partikel $-k a h$ berfungsi untuk memberi tanda pada bagian yang dipentingkan atau penegasan dapat dilihat dari kalimatkalimat berikut. Misalnya pada contoh

"Sudahkah Anda salat?"

Dilihat dari reaksi jawaban yang

diberikan, Chaer(2009:190) membedakan kalimat interogatif menjadi lima, yaitu sebagai berikut.

a. Kalimat interogatif yang meminta pengakuan jawaban "ya", "tidak", atau

"bukan". Kalimat tersebut dapat dapat dibentuk dengan cara:

1) Memberi tanda tanya diakhir kalimat.

Contoh: "Paragraf itu berpola induktif?"

2) Memberi kata tanya apakah di muka sebuah kalimat.

Contoh: "Apakah itu paragraf berpola induktif?"

3) Memberi partikel tanya kah pada bagian kalimat yang ingin ditanyakan. Dalam hal ini bagian kalimat yang mendapat tambahan partikel di tempatkan pada awal kalimat.

Contoh: "Berpola induktifkah paragraf itu?"

Kalimat jawaban untuk kalimat interogatif ini dapat dalam bentuk singkat atau bentuk lengkap. Jawaban untuk pertanyaan di atas bisa "Ya" atau "Ya, paragraf itu berpola induktif" 
atau bisa dijawab dengan "Tidak" atau "Paragraf tersebut tidak berpola induktif"

b. Kalimat interogatif yang meminta keterangan mengenai salah satu unsur kalimat.

Kalimat interogatif yang meminta keterangan mengenai salah satu unsur kalimat dibentuk dengan bantuan kata tanya (apa, siapa, mana , berapa, dan kapan) sesuai dengan bagian mana yang ditanyakan.Untuk menanyakan benda digunakan kata tanya apa. Contoh: "Apa profesi sang narasumber?"

1) Kata tanya siapa digunakan untuk menanyakan orang. Contoh: "Siapa yang menjadi tokoh utama dalam drama tersebut?"

2) Kata tanya mana digunakan untuk menanyakan keberadaan benda. Contoh:

"Mana bukuku?" Sedangkan untuk menanyakan tempat keberadaan, tempat kedatangan, dan tempat tujuan lebih tepat ditambahkan preposisi (di, ke dan dari) di muka kata mana. Contoh: "Di mana rumahmu?"

3) Kata tanya berapa untuk menanyakan jumlah. Contoh: "Berapa harga buku itu?"

4) Kata tanya kapan untuk menanyakan waktu. Contoh: "Kapan bukuku akan kau kembalikan?"

c. Kalimat interogatif yang meminta alasan

Kalimat interogatif yang meminta jawaban berupa "alasan" dibentuk dengan bantuan kata tanya mengapa atau kenapa. Contoh:

"Mengapa Karim sangat membenci Mimi?" d. Pikiran orang lain. Kalimat interogatif yang meminta pendapat atau buah

Kalimat interogatif yang meminta pendapat atau buah pikiran dibetuk dengan bantuan kata tanya bagaimana. Contoh:

"Bagaimana watak Karim?"

e. Kalimat interogatif yang menyuguhkan.

Kalimat interogatif menyuguhkan, sebenarnya mengharapkan jawaban untuk menguatkan yang ditanyakan. Kalimat ini juga disebut kalimat pertanyaan retoris. Contoh: "Anda tahu bagaimana saya, bukan?"

Penelitian ini menggunakan rancangan kualitatif. Bogman dan Taylor (dalam Moleong, 2001:3) mendefinisikan penelitian kualitatif sebagai prosedur penelitian yang menghasilkan data deskripsi berupa data-data tertulis atau lisan dari orang-orang atau perilaku yang diamati. Penelitian ini menggunakan data tertulis yang berupa butir-butir soal evaluasi pada Buku Sekolah

Elektronik(BSE) karangan Adi Abdul Somad,ddk. Data yang digunakan dalam penelitian ini adalah butir-butir soal evaluasi pada Buku Sekolah

Elektronik(BSE) terbitan Pusat Perbukuan

Departemen Pendidikan Nasional karangan Adi Abdul Somad,dkk.

Buku tersebut merupakan buku yang dapat digunakan dalam satu periode pembelajaran sehingga terdiri dari dua semester, yaitu semester genap dan semester 
ganjil. Oleh karena itu sumber data penelitian ini adalah uji kompetensi pada semester I dan semester II yang terdapat pada buku tersebut.

Pelaksanaan metode dokumentasi dalam penelitian ini adalah sebagai berikut:

1) peneliti menyiapkan sumber data yaitu buku Aktif dan Kreatif Berbahasa Indonesia untuk Kelas XI SMA/MA Program IPA dan IPS terbitan Pusat Perbukuan Departemen Pendidikan Nasional (BSE) yang

telah diunduh dari internet;

2) peneliti mencatat butir-butir soal semester I dan II pada buku Aktif dan Kreatif Berbahasa Indonesia untuk

Kelas XI SMA/MA Program IPA dan IPS terbitan Pusat Perbukuan Departemen Pendidikan Nasional (BSE) peneliti memindah data dengan cara mencatat data ke dalam instrumen pembantu pengumpul data.

Langkah-langkah dalam analisis data adalah sebagai berikut.

1) Telaah data

Data yang telah terkumpul dipilih dan dipastikan bahwa data tersebut adalah data yang diinginkan.

2) Pemberian kode

Pengkodean ini dilakukan untuk memudahkan peneliti dalam mengklasifikasikan data. Kode-kode tersebut adalah sebagai berikut.

a) Dek untuk kalimat berjenis deklaratif

b) Int untuk kalimat berjenis interogatif

c) Imp untuk kalimat berjenis imperatif

d) C1 untuk tingkat pengetahuan

e) C2 untuk tingkat pemahaman

f) C3 untuk tingkat penerapan

g) C4 untuk tingkat analisis

h) C5 untuk tingkat sintesis

i) C6 untuk tingkat evaluasi

j) I menunjukkan soal terdapat pada semester 1 (gasal)

k) II kode untuk semester II.(genap)

1) obj menujukkan bentuk soal objektif

m) esai menunjukkan bentuk soal esai

3) Pengklasifikasian data

Data-data yang telah dikumpulkan dan diberi kode kemudian diklasifikasikan dalam setiap katagori berdasarkan tingkat kognitif dan bentuk kalimatmnya.

4) Pendeskripsian data

Data yang telah diklasifikasikan selanjutnya dideskripsikan berdasarkan tingkat kognitif dan bentuk kalimatmnya. 


\section{PEMBAHASAN}

Dalam penelitian ini dibahas tiga

hal, yaitu (1) bentuk uji kompetensi (2)

tingkat kognitif uji

kompetensi berdasarkan teori

Bloom; dan (3) bentuk kalimat uji

kompetensi pada Buku Sekolah Elektronik (BSE).

\section{Bentuk Tes Uji Kompetensi}

Buku Aktif dan Kreatif Berbahasa

Indonesia untuk Kelas XI

SMA/MA Program IPA dan IPS

atau yang disebut dengan Buku Sekolah

Elektronik (BSE) karangan Adi Abdul

Somad,dkk terdiri atas dua semester, yaitu

semester 1 (gasal) dan semester 2 (genap).

Pada setiap semester terdapat evaluasi

yang disebut dengan uji kompetensi. Uji

kompetensi pada semester 1 terdiri atas 30

butir soal sedangkan pada semester 2

terdiri atas 28 butir soal sehingga jumlah

seluruhnya 58 butir soal. Setelah

dilakukan analisis data, diketahui

keseluruhan butir soal uji kompetensi

tersebut berbentuk tes objektif berjenis

pilihan ganda.

Berdasarkan struktur soalnya, soal uji kompetensi yang berbentuk tes objektif berjenis pilihan ganda pada Buku Sekolah Elektronik (BSE) dapat digolongkan menjadi 4, yaitu (1) pertanyaan langsungdaftar pilihan, (2) pernyataan tidak lengkap-daftar pilihan, (3) tekspenyataan tidak lengkap-daftar pilihan, dan (4) perintah- teks-pernyataan tidak lengkapdaftar pilihan.

\section{Tingkat Kognitif Soal Uji}

\section{Kompetensi Berdasarkan Teori Bloom}

Sebagai bahan evaluasi, soal uji kompetensi memiliki tingkatan kognitif. Tingkat kognitif soal uji kompetensi pada Buku Sekolah Elektronik (BSE) karangan Adi Abdul Somad,dkk dapat dipaparkan bahwa tingkat evaluasi belum tampak, sehingga tidak memenuhi proporsi yang tepat untuk siswa SMA. Pada tingkat pengetahuan $(C 1)$ ditemukan 8 butir soal dengan persentase $14 \%$, tingkat pemahaman (C2) ditemukan 22 butir soal dengan persentase $38 \%$, tingkat penerapan $(C 3)$ ditemukan 10 butir soal dengan persentase $18 \%$, tingkat analisis (C4) ditemukan 16 butir soal dengan persentase $27 \%$, tingkat sintesis (C5) ditemukan 2 butir soal dengan persentase 3 $\%$ dan tidak ditemukan butir soal pada tingkat evaluasi (C6) 0 \% . Untuk mengetahui lebih jelas dapat dilihat pada tabel berikut ini.

\begin{tabular}{|l|l|c|c|}
\hline No & Tingkat Kognitif & $\begin{array}{c}\text { Jumlah } \\
\text { Soal }\end{array}$ & Persentase \\
\hline 1. & Pengetahuan & 8 & $\%$ \\
2. & Pemahaman & 22 & $\%$ \\
3. & Penerapan & 10 & $\%$ \\
4. & Analisis & 16 & $\%$ \\
5. & Sintesis & 2 & $\%$ \\
6. & Evaluasi & 0 & $\%$ \\
\hline & Jumlah & 58 & \\
\hline
\end{tabular}


Tabel 2. Uji Kompetensi Dilihat dari Segi Kognitif

\section{Bentuk Kalimat Uji Kompetensi}

Bentuk kalimat butir-butir soal yang terdapat pada Buku Sekolah Elektronik (BSE) karangan Adi Abdul Somad,dkk dilihat dari segi sintaksis ditemukan 55 soal yang berbentuk deklaratif, 3 soal yang berbentuk interogatif, dan tidak ditemukan soal yang berbentuk kalimat imperatif.

\section{PENUTUP Kesimpulan}

Berdasarkan hasil penelitian dapat disimpulkan sebagai berikut. 1) Bentuk tes soal uji kompetensi pada Buku Sekolah Elektronik (BSE) ditemukan semua soal berbentuk tes objektif berjenis pilihan ganda. Berdasarkan struktur soalnya, soal uji kompetensi tersebut dilogongkan menjadi 4, yaitu (1) pertanyaan langsungdaftar pilihan terdapat 25 soal, (2) pernyataan tidak lengkapdaftar pilihan terdapat 19 soal, (3) tekspenyataan tidak lengkap-daftar pilihan terdapat 6 soal, dan (4) perintah-tekspernyataan tidak lengkapdaftar pilihan terdapat 30 soal.

2) Tingkat kognitif soal uji kompetensi pada Buku Sekolah Elektronik (BSE) dilihat berdasarkan teori Bloom ditemukan tingkat pengetahuan $(C l)$ terdapat 8 butir soal dengan persentase
$14 \%$, tingkat pemahaman (C2) terdapat 22 bitir soal dengan persentase $38 \%$, tingkat penerapan (C3) terdapat 10 butir soal dengan persentase $18 \%$, tingkat analisis (C4) terdapat 16 butir soal dengan persentase $27 \%$, tingkat sintesis (C5) terdapat 2 butir soal dengan persentase $3 \%$ dan tidak ditemukan soal dengan tingkat evaluasi(C6) dengan persentase $0 \%$. Hasil tersebut tidak sesuai dengan perimbangan proporsi tingkat kognitif untuk siswa Sekolah Menengah Atas (SMA).

3) Bentuk kalimat soal uji kompetensi (dilihat dari segi sintaksis) pada Buku Sekolah Elektronik (BSE) ditemukan 55 butir soal yang berbentuk deklaratif, 3 butir soal yang berbentuk interogatif, dan tidak ditemukan soal yang berbentuk kalimat imperatif. Dengan demikian dapat disimpulkan bentuk kalimat deklaratif sangat mendominasi dan kalimat imperatif tidak ditemukan sama sekali.

Bentuk kalimat deklaratif yang banyak ditemukan berhubungan dengan bentuk butir-butir soal yang menunjukkan semua butir soal berbentuk objektif. Pada butir soal yang berbentuk objektif siswa tidak dituntut untuk meguraikan jawaban yang dimilikinya, namun berdasar atas pilihan yang sudah tersedia, sehingga 
kalimat soal yang digunakan berupa kalimat

deklaratif.

\section{DAFTAR PUSTAKA}

Arikunto, Suharsimi. 2006.

Prosedur Penelitian: Suatu

Pendekatan Praktik. Jakarta: Rineka

Cipta.

Chaer, Abdul. 2009. Sintaksis

Bahasa Indonesia (Pendekatan

Proses). Jakarta:

Rineka Cipta.

Purwanto, M. Ngalim.1992. Prinsip-prinsip

dan Teknik Evaluasi

Pengajaran. Bandung: Remaja

Karya.

Pers Depdiknas.2008. Ebook sebagai Alternatif Solusi Mahalnya Buku.

http://www.depdiknas.go.id /content.php?content=file_detailberita \& $\mathrm{KD}=215$

Somad, Adi Abdul, Aminudin dan Yudi Irawan. 2008. Aktif dan Kreatif Berbahasa Indonesia untuk Kelas XI SMA/MA Program IPA dan IPS. Jakarta: Pusat Perbukuan Departemen Pendidikan Nasional.

Sukardi. 2009. Evaluasi Pendidikan: Prinsip dan Operasionalnya. Jakarta: Bumi Aksara.

Suladi, Wiwik Dwi Astuti dan K.Biskoyo.2000. Keterbacaan Kalimat Bahasa Indonesia dalam Buku Pelajaran SLTP. Jakarta: Pusat Bahasa. 